This work is licensed under a Creative Commons Attribution 4.0 International License.

Ovaj rad dostupan je za upotrebu pod međunarodnom licencom Creative Commons Attribution 4.0.

Anja Nikolić-Hoyt

\title{
PARALELNE KORPUSNE GLOSE I DOKUMENTACIJSKI POTENCIJAL BENEŠIĆEVA RJEČNIKA
}

dr. sc. Anja Nikolić-Hoyt, Zavod za lingvistička istraživanja Hrvatske akademije znanosti i umjetnosti, anhoyt@hazu.hr, Zagreb

izvorni znanstveni članak

UDK 811.163.42'374 Benešić, J.

rukopis primljen: 27. 9. 2017.; prihvaćen za tisak: 22. 11. 2017.

U radu je riječ o dokumentacijskom potencijalu Benešićeva književnojezičnog rječnika, koji posebno dolazi do izražaja uvođenjem paralelnih korpusnih glosa. Ovaj nov metodološki postupak supostavljanja korpusnih glosa koje pripadaju različitim izdanjima istoga djela, uveden je od 14. sveska radi dokumentiranja jezičnih (i nejezičnih) praksi stogodišnjega formativnog razdoblja (od preporoda do I. G. Kovačića) u povijesti hrvatskoga jezika i književnosti.

Ključne riječi: hrvatski jezik; Benešićev rječnik; paralelne korpusne glose

\section{Uvod}

U današnje vrijeme preispitivanja i prevrednovanja svekolikoga naslijeđa prošlosti, svega onoga što su prohujali vjekovi ostavili za sobom i što su svojim genijem i upornim nastojanjima iznjedrila ranija pokoljenja, a što je ugrađeno u temelje postojanja i funkcioniranja suvremenoga svijeta, možemo se pitati i kakva je uloga leksikografije, odnosno rječnika danas i kakva je njihova očekivana budućnost. Ostavljajući po strani povijest nastanka rječnika, njihov razvoj te mijene njihova izraza i sadržaja koje su rezultirale golemom raznolikošću leksikografskih ostvarenja kojima se danas služimo, fokus svoga interesa usmjerit ćemo tek na jednu dimenziju 
rječničkoga teksta, koja je ponekad tek implicitno, no u slučaju Rječnika o kojemu ćemo govoriti, u znatnoj mjeri eksplicitno iskazana. Riječ je o onoj dimenziji po kojoj rječnik svjedoči, to jest dokumentira stvarnost iz koje je izrastao, svekolike jezične i nejezične prakse svoga vremena i, dakako, različite svjetonazorske sadržaje. Međutim, ta dimenzija svakoga rječničkog teksta nije vezana za jedno vrijeme jer je raznovremenska odnosno svevremenska, to jest postoji u svakom vremenu.

Ovaj se rad bavi dokumentacijskim potencijalom paralelnih korpusnih glosa, koje se kao nov metodološki postupak javljaju u 14. svesku Rječnika hrvatskoga književnoga jezika od preporoda do I. G. Kovačića Julija Benešića. Premda paralelni korpus podrazumijeva dvojezični ili višejezični korpus koji sadrži niz tekstova na dva ili više jezika (Simeon 2002: 209), u našem ga radu rabimo u unekoliko modificiranu značenju. Prije svega, budući da se natuknički članci u navedenu rječniku oprimjeruju citatima, a ne cjelovitim korpusima, govorimo o korpusnim glosama. U paralelnim pak korpusnim glosama ne supostavljamo različite jezike, nego različita izdanja istoga književnog djela radi dokumentiranja vanjske i unutarnje povijesti hrvatskoga jezika u formativnome razdoblju njegova razvoja. ${ }^{1}$

\section{Rječnik hrvatskoga književnoga jezika od preporoda do I. G. Kovačića}

Rječnik hrvatskoga književnoga jezika od preporoda do I. G. Kovačića, o kojemu ćemo ovdje govoriti, odraz je jezičnih i nejezičnih praksi s kraja 19. i prve polovice 20. stoljeća, dakle u vrijeme burnih promjena te usustavljivanja i ustaljivanja novoštokavskoga standardnog jezika. Kao i svim drugim prevratnim vremenima i ovomu su vremenu svojstvena brojna previranja, kolebanja, različiti te nerijetko oprečni stavovi i ponekad nesumjerljivi postupci.

1 Unutrašnja je imanentna povijest jezika [...] Vanjska se povijest bavi funkcioniranjem jezika u nekom društvu [...]. Nikako nije riječ o dvjema posve odijeljenim povijestima [...] Vanjska se povijest književnoga jezika bavi [...] odnosom vlasti prema jeziku, jezičnom politikom, službenim propisima o jeziku, izborom korpusa, odnosno upotrebom jezika, a unutrašnja prati pravopisno i jezično ujednačivanje, odnosno razvoj pravopisne i jezične norme (Tafra 2011: 186-187). 


\subsection{Iz povijesti}

Nastao na poticaj Miroslava Krleže, tadašnjega potpredsjednika Jugoslavenske akademije znanosti i umjetnosti, ovaj je Rječnik izrastao iz potrebe, koja se počela javljati već u međuratnom razdoblju, za izradom i izdavanjem rječnika hrvatskoga književnog jezika koji bi nadomjestio praznine i nedostatke postojećih rječnika, poglavito Broz-Ivekovićeva Rječnika hrvatskoga jezika iz 1901. godine. ${ }^{2}$ Naime, onodobni su rječnici, pod utjecajem rastućega štokavskog purizma, nudili krnju sliku o leksiku hrvatskoga jezika u kojoj hrvatska književnojezična tradicija nije bila u zadovoljavajućoj mjeri zastupljena (Nikolić-Hoyt 2010: 62).

Izrada takva rječnika bila je kasnih četrdesetih godina prošloga stoljeća povjerena Juliju Benešiću, književniku i jezikoslovcu, prevoditelju i teatrologu. Međutim Benešić, na žalost, nije stigao završiti započeti rad, a dio se rječnika na kojemu je radio pojavio u tisku tek 1985. godine, tridesetak godina nakon njegove smrti. Naime, od 1985. do 1990. godine objavljeno je dvanaest svezaka zaključno sa slovom $\mathrm{R}$ (protivan-rzati), a tek se 2008. godine u Zavodu za lingvistička istraživanja Hrvatske akademije znanosti i umjetnosti nastavilo s radom na njegovu dovršavanju. 2013. godine objavljen je prvi u nizu novih svezaka, voluminozni 13. svezak (s-spužvast), koji karakteriziraju novi metodološki postupci, nova rješenja te bilježenje korpusnih glosa dostojno povjerenja. Uz to, a različito od prvih dvanaest svezaka u kojima se uz citatne potvrde bilježe samo prezimena citiranih autora, u novim se svescima uz svaki citat donose širi podaci o izvorima, to jest podaci o autoru, naslovu djela, godini izdanja i broju stranice. Primjerice, dok se uz korpusnu glosu koja u 8. svesku (1988) oprimjeruje natuknicu nijansa nalazi samo ime autora - Sve, što je samo jedna pa i najneznatnija nijansa više inspiracije, to je za gospodu specijaliste patološki slučaj (Krleža) - u 14. se svesku uz istu glosu koja ovdje ukazuje na uporabni kontekst natuknice stenjevački donose širi podaci o izvoru Dakako, to je gospodi doktorima bolesno, to je za gospodu neurologe stenjevački način mišljenja, sve što je samo jedna pa i najneznatnija niansa više inspiracije, to je [...] „patološki slučaj” (Krleža, Novele, 1937: 253)33. Drugi u nizu novih

2 „Iveković-Brozov Rječnik hrvatskoga jezika iz godine 1901. [...] nije ni predstavljao hrvatski književni jezik nego je bio sazdan najvećim dijelom na osnovama na kojima je počivala i Maretićeva velika Gramatika i stilistika" (Hamm 1985: IX).

3 Dakako, riječ je o dvama različitim izdanjima, no iz podatka o autoru koji donosi 8. svezak ne možemo zaključiti kojemu izdanju pripada glosa koju navodi. 
svezaka, 14. svezak (spužvica-švrljuga), završen je krajem 2016. i objavljen početkom 2017. godine. Tomu su svesku svojstveni i opet novi, još produbljeniji metodološki postupci, o čemu će se više govoriti u nastavku ovoga rada.

\subsection{O sadržaju}

Utemeljivši svoj Rječnik na citatima iz djela ponajboljih više od stotinu hrvatskih književnika koji su stvarali od sredine 19. do sredine 20. stoljeća - najstariji među njima Antun Mihanović, a najmlađi pak Ivan Goran Kovačić i samo tri žene među njima (Ivana Brlić-Mažuranić, Zdenka Marković i Adela Milčinović, što znači da nema Dragojle Jarnević, nema Zagorke ni drugih priznatih autorica toga vremena) - Benešić je ponudio jedinstvenu sliku hrvatskoga jezika, ponajprije njegova leksika, u stogodišnjem razdoblju njegova razvoja. ${ }^{4}$ Zahvaljujući autorovu otvorenom, nenormativnom pristupu korpusu ekscerpiranih djela Rječnik hrvatskoga književnoga jezika od preporoda do I. G. Kovačića opisuje sve čega je u

4 Benešićev Popis autora od kojih su uzimani citati uključuje stotinjak pisaca: Antun Mihanović (r. 1796.), Nikola Tommaseo, Stanko Vraz, Dimitrije Demeter, Antun Nemčić, Stjepan Ilijašević, Ivan Mažuranić, Mirko Bogović, Ivan Kukuljević Sakcinski, Mate Vodopić, Petar Preradović, Ivan Trnski, Grga Martić, Janko Tombor, Adolfo Veber-Tkalčević, Ivan Perkovac, Ilija Okrugić, Janko Jurković, Luka Botić, Mihovil Pavlinović, August Šenoa, Vilim Korajac, Lavoslav Vukelić, Ivan Dežman, Josip Eugen Tomić, Ferdo Becić, Franjo Marković, Ivan Zahar, Franjo Ciraki, Andrija Palmović, Eugen Kumičić, Hugo Badalić, Rikard Jorgovanić, Ante Kovačić, Ksaver Šandor-Gjalski, Jovan Hranilović, Ivo Vojnović, Josip Kozarac, Nikola Tordinac, Fran Mažuranić, Vjenceslav Novak, Rikard Katalinić-Jeretov, Jure Turić, August Harambašić, Janko Leskovar, Josip Draženović, Edhem Mulabdić, Silvije Strahimir Kranjčević, Ante Tresić-Pavičić, Osman-Aziz-Ivan Miličević i Osman Hadžić, Iso Velikanović, Vladimir Tresčec, Tugomir Alaupović, Viktor Car Emin, Branimir Livadić, Milkan Lovinac-Milko pl. Vukelić, A. G. Matoš, Dinko Šimunović, Ivana Brlić- Mažuranić, Živan Bertić, Vladimir Vidrić, Dragutin Domjanić, Milan Begović, Vladimir Nazor, Franjo Horvat-Kiš, Milan Ogrizović, Andrija Milčinović, Ivan Krnic, Mihovil Nikolić, Josip Kosor, Joza Ivakić, Adam Kostelić, Hugo Sedlaček, Milutin Cihlar Nehajev, Iso Cepelić, Marin Bego, Božo Lovrić, Niko Andrijašević, Zdenka Marković, Mato Hanžeković, Ivan Kozarac, Mate Košćina, Fran Galović, Mihovil Pavlek Miškina, Vilko Gabarić, Nikola Polić, Niko Bartulović, Danko Angjelinović, Tin Ujević, Slavko Kolar, Miroslav Krleža, August Cesarec, Ahmet Muradbegović, A. B. Šimić, Gustav Krklec, Luka Perković, Dobriša Cesarić, Slavko Batušić, Đuro Sudeta, Nikola Šop, Hasan Kikić, Vjekoslav Kaleb, Dragutin Tadijanović, Alija Nametak, Petar Šegedin, Ivan Dončević, Olinko Delorko, Ranko Marinković, Ivan GoranKovačić (r. 1913.). Osim spomenutih autora ekscerpirane su i zbirke narodnih pjesama Matice hrvatske, Luke Ilića Oriovčanina i zbirke narodnih pripovjedaka Mijata Stojanovića te Kušarovo Narodno blago. 
hrvatskome jeziku u jednome odsječku njegova vremena bilo, i to u njegovoj vanjskoj i unutrašnjoj povijesti. A bila je to raznolikost supostojećih sustava, kako grafijskih i pravopisnih, tako i sadržajnih i ideoloških koja je pak svojstvena prevratnim vremenima kao što je i bilo spomenuto stogodišnje razdoblje.

Razdoblje na koje se odnosi građa Benešićeva rječnika (od polovice 19. stoljeća do sredine 20. stoljeća) vrijeme je razvoja odnosno kodifikacije i stabilizacije hrvatskoga standardnog jezika ili preciznije, to je razdoblje od kodifikacije ilirskoga odnosno općehrvatskoga jezičnog standarda do kodifikacijskoga zaokreta prema artikuliranju i pobjedi jezičnog unitarizma. Naime, prema Brozovićevoj periodizaciji povijesti hrvatskoga književnog i standardnog jezika, u kojoj razlikujemo šest razdoblja: tri „predstandardna” (do kraja 15. stoljeća, 16. stoljeće, 17. i prva polovica 18. stoljeća) i tri „razdoblja razvoja jezičnoga standarda” (od polovice 18. stoljeća do preporoda, od preporoda do kraja 19. stoljeća i 20. stoljeće) (Brozović 2008: $33 / 34)^{5}$, Benešićev rječnik pripada dvama posljednjim standardizacijskim periodima. Pritom se u kroatističkoj literaturi posljednja dva razdoblja razvoja jezičnoga standarda dijele na više podrazdoblja. Primjerice, Samardžija ih (1995) u 20. stoljeću razlikuje čak pet: 1901-1918, 1918-1941, 1941-1945, 1945-1990, 1990- , od kojih su za Benešićev rječnik relevantna i razlikovna prva tri, a u izvjesnom smislu i četvrto jer su promjene, koje su se pod utjecajem izrazito konvergentne jezične politike u doba Jugoslavije događale u hrvatskome jeziku poslije 1945. godine, rezultirale iščeznućem niza izvornih hrvatskih riječi i poraba, zabilježenih, srećom, u Benešićevu rječniku. Drugim riječima, promatrano iz perspektive današnjih jezičnih prilika Benešićev rječnik posredno svjedoči i o napuknuću leksičkoga kontinuiteta hrvatskoga jezika.

\subsubsection{Od preporoda do pretkraj 19. stoljeća}

Uzimajući u obzir cijelo stoljeće pisane odnosno tiskane hrvatske riječi možemo reći, ne ulazeći, međutim, u opširnije ekskurse da u Benešićevu rječniku kao njegovu vjernom svjedočanstvu nalazimo:

5 Brozovićev sintetički nacrt povijesti hrvatskoga književnog jezika iz 2008. godine objavljen je prvotno u zborniku Hrvatska književnost u evropskom kontekstu 1978. pod naslovom „Hrvatski jezik, njegovo mjesto unutar južnoslavenskih i drugih slavenskih jezika, njegove povijesne mijene kao jezika hrvatske književnosti”. 
(i) primjere samobitnosti hrvatskoga jezika - izvornu hrvatsku grafiju, pravopis, stare hrvatske množinske padeže i virtuozne tvorbe

Uz staru grafiju, takozvano rogato e (ě) na mjestu staroga jata, dvoslove èr ili àr za slogotvorni / $/$ te dva grafema dj i gj za /đJ/ i tj/ć/, književna djela 19. stoljeća, pisana jezikom i (morfonološkim) pravopisom ilirske odnosno zagrebačke filološke škole, karakteriziraju stari hrvatski množinski padeži i virtuozne tvorbe. Prije svega, u hrvatskih je pisaca 19. stoljeća istaknuta težnja ka uporabi dočetka - ah u genitivu množine imenica svih triju deklinacija ${ }^{6}$ koji je, nasuprot nastavku - $a$ kao dijelu Karadžićeve jezične koncepcije, bio odlikom ilirske, dakle hrvatske norme:

To bijahu ljudi prosti [...] mjesto kaputah, frakah i surkah, imali su na sebi gunjce, surine i čohe (Kukuljević, Dva Slavena, 1859, 85);

... da je Gojko, istinabog, dopanuo několiko ranah stranom od kopita konjah, stranom time, što su kola prošla preko njega ... (Bogović, Pripověsti, 1859, 5);

Stekoše si ime od junakah, / Šest kapralah, do šest Gradiščanah (Ilić-Oriovčanin, Lovorike, 1874, 189);

... se je širenjem tjelesne mase sve to više stezala umna glavnica ubogoga čovjeka, i sada već življaše skoro o samih nekoliko poslovicah i drugih stereotipnih rečenicah (Jurković, Sabrane pripoviesti II, 1881, 117);

Mani se gusalah, strunah i pjesamah. Pustimo to našoj prijateljici Draginji. Ona i onako ljepše pjeva od tebe. Neide ti. I strune pucaju I grlo hrapavo ... (Kovačić, Fiškal, 1882, 93).

Ostavljajući po strani raspravu o statusu ilirskoga genitivnoga -ah odnosno o dočetnom - $h$ jer nastavak - $a$ nije bio sporan (Tafra 1995: 109), dodajmo još da ilirsku književnojezičnu normu također karakteriziraju i različiti nastavci u DLI množine imeničke i pridjevno-zamjeničke deklinacije ${ }^{7}$,

6 Zapravo je riječ o trima dočecima: -ah, -ih (u genitivu množine) i -uh (u genitivu i lokativu duala) (Tafra 1995: 111-112).

7 U Slovnici hèrvatskoj istaknuti ilirski gramatičar zagrebačke škole Antun Mažuranić daje sljedeće množinske sklonidbene uzorke: N. jèlen-i, G. jèlēn-āh, D. jèlen-ōm, A. jèlen-e, V. 
suprotno njihovu novoštokavskomu sinkretizmu. ${ }^{8}$ Naime, hrvatska je gramatička tradicija (od Kašića nadalje) dopuštala dubletne nastavke u množinskim padežima, dakle i sinkretske i neizjednačene, normirane ilirskim gramatikama. Ta je tradicija prekinuta ilirskom jezičnom koncepcijom zbog ideoloških razloga jer su stariji nastavci objedinjavali razdvojeno tronarječno tkivo hrvatskoga jezika (Tafra 1995: 160):

Obkoljeno sa svih stranah stogodnjacim hrastovi na zelenoj čistini oko bistra zdenca sědi jato slavoskih sokolovah, četa slavonskih hajdukah ... (Tombor, Hajdukova zaručnica, 1854, 395);

Lasno je voditi razbludno kolo po svilenih livadicah slavonskih [...] ali preskakivati stěnovlje, propinjati se po klisurah i kukovih ... (Veber-Tkalčević, Listovi o Italiji, 1861, 16);

Valjda Vam je dosadan taj zadnji plod Zolina pera s toga, što radi odveć o ženskih stvarih [...] To bi bio razlog, da se vama mužkarcem tim većma mili! (Vojnović, Perom i olovkom, 1884, 49);

Kao izvan sebe pritrča $k$ njoj [...] i uhvativ ju za bielu, meku ručicu, stade ju obasipati vrućimi cjelovi i suzami (Tomić, Kapitanova kći, 1884, 23).; One udate, što po glupom običaju uvijaju bielom maramom glavu i lice [...] nemarimo ni gledati, ali tim radje napast ćemo oči na stasitih i jedrih sekah ... (Tomić, Kapitanova kći, 1884, 85);

Što se medju prijatelji razgovara; - to je svojina tih prijatelja $i$ njihova družtva, a medju čestitimi ljudmi ne ide nikada dalje (Gjalski, Pod starimi krovovi, 1886, 131).

jèlen-i, L. jèlen-īh, I. jèlen-ī; N. sêl-a, G. sél-āh, D. sèl-ōm, A. sêl-a, V. sël-a, L. sël-ìh, I. sël-i (Mažuranić 1859 [2008]: 57/58); N. žèn-e, G. žèn-ah, D. žèn-ām, A. žèn-e, V. žèn-e, L. žèn-ah, I. žèn-ami (Mažuranić 1859 [2008]: 64).

8 U svome kronološkom pregledu najvažnijih hrvatskih morfoloških inovacija Matasović datira sinkretizam D i I mn. u sredinu 16. stoljeća - na različite načine i ne u isto vrijeme, u svim dijalektima i deklinacijskim razredima - a širenje sinkretizma množinskih padeža (DI mn.) i na L mn. u 17. stoljeće, kada započinju i prvi koraci prema standardizaciji hrvatskoga jezika (Matasović 2008: 305). 
Međutim, s Brozovim fonološki koncipiranim Hrvatskim pravopisom (1892) i Maretićevom Gramatikom i stilistikom hrvatskoga ili srpskoga književnog jezika (1899) prevladala je odnosno pobijedila je Karadžićeva književnojezična norma te su početkom 20. stoljeća knjige bile već prilično povukovljene, daničićizirane (Tafra 1995: 126), a daljnji je razvoj hrvatskoga jezika obilježen novoštokavskom jezičnom reformom i fonološkim pravopisom. O kodifikacijskom zaokretu prema jezičnom unitarizmu svjedoče korpusne glose iz paralelnih izdanja u Benešićevu rječniku:

Valjda Vam je dosadan taj zadnji plod Zolina pera za to, što radi odviše o ženskim stvarima [...] To bi bio razlog, da se vama muškarcima tim većma mili (Vojnović, Perom i olovkom, 1910, 46);

Što se među prijateljima razgovara, to je svojina tih prijatelja $i$ njihova društva, a među čestitim ljudima ne ide nikada dalje (Gjalski, Pod starim krovovima, 1929, 112);

Kao izvan sebe pritrča $k$ njoj [...] i uhvativši ju za bijelu, meku ručicu, stade ju obasipati vrućim cjelovima i suzama (Tomić, Kapetanova kći, 1935, 37).; One udate, što po glupom običaju uvijaju bijelom maramom glavu i lice [...] ne marimo ni gledati, ali tim radije napasti ćemo oči na stasitim i jedrim sekama ... (Tomić, Kapetanova kći, 1935, 138/139).

Napokon, književnu produkciju hrvatskih pisaca 19. stoljeća karakterizira i raskošna tvorbena produktivnost i kreativnost. Važno je, međutim, naglasiti da tvorenice o kojima je riječ nisu ishitrene i proizvoljne, sve se one mogu uklopiti u postojeće tvorbene modele hrvatskoga jezika, no ponajprije u izvođenje odnosno slaganje ${ }^{9}$. Već nemalen broj primjera koji slijede jasno svjedoči o tvorbenoj produktivnosti i kreativnosti koja je u djelima hrvatskih pisaca 19. stoljeća rezultirala svojevrsnom leksičkom eksplozijom, to jest orječivanjem najrazličitijih koncepata i konceptnih odnosa. Važno je također primijetiti da su sve tvorenice motivacijski pot-

9 Za potrebe ovoga rada nije bilo nužno detaljno analizirati vrste i rezultate tvorbenih procesa, premda bi se tvorenice koje nalazimo u Benešića mogle razvrstati istančanije i po različitim kriterijima. Usp. Tafra i Košutar navode čak 13 vrsta tvorenica po rezultatu tvorbe: 1 . izvedenice 2 . složenice 3 . kraćenice 4 . posuđenice 5 . prevedenice 6 . oživljenice 7. sastavljenice 8 . višerječnice 9. promjenjenice 10. naličnice 11 . onimi 12 . eponimi 13. homonimi (Tafra i Košutar 2009: 93). 
puno ili najvećim dijelom transparentne: bezdjelica 'besposlica; besposličar' (Kovačić, Šenoa), bezdjetka 'što ne može imati djece, nerotkinja' (Novak), beznišnjak 'čovjek, koji nema ništa golov, praznov, siromah' (Kumičić), bikovina 'pristojba od neženjenih' (Šenoa), bilost 'što je bilo, prošlost' (Preradović), bližika 'rođak' (Nehajev), bludožeđ (Lovinac), brditi 'penjati se uzbrdo' (Kranjčević), brusipeta 'koji bježi' (Šenoa), dohodarina 'porez na dohodak' (J. Kozarac), dokončak 'zaključak' (Tomić), domaćnost 'privatni život' (Veber-Tkalčević), dosebica 'sebičnik, egoist' (Stojanović), douha 'vijest, glas' (I. Kozarac), glasosklađe 'harmonija' (Nemčić), glumiona 'kazalište' (Trnski, Šenoa), gradovid 'tlocrt, plan grada' (Veber-Tkalčević), jedionica 'blagovaonica' (Tresčec), jezikočistitelj (Nemčić), kopnjak 'čovjek s kopna, kontinentalac' (Veber-Tkalčević), ljepšalica 'koja umije ljepšati, učiniti lijepim' (J. Kozarac), mesojeđe 'vrijeme od Božića do korizme' (Stojanović, Begović), mignuće 'trenutak' (Kukuljević) ${ }^{10}$, stepihleb 'raspikuća' (Kukuljević, Tomić), stezulja 'luđačka košulja' (Kranjčević), strmogled 'žalosna vrba' (Kukuljević, Kovačić, Gjalski, Krleža, Domjanić, Šenoa, Harambašić), svetokrilac 'anđeo' (Jorgovanić, Harambašić), svjetlač 'onaj koji polira srebrno posuđe do visokog sjaja' (Tresić-Pavičić) i brojne druge. Raskoš tvorbe i bogata leksička produkcija ogledaju se također u razvijenoj leksičkoj i gramatičkoj sinonimiji onoga vremena. Primjerice, bezvjerac, bezvjernik u značenju 'onaj koji nema vjere' odnosno bezbožac, bezbožnik, bezbožnjak 'ateist', ili pak čovječac, čovječak, čovječić, čovječuljak, čovuljak, čovuljić u značenju 'dem. od čovjek' te samoubijstvo, samoubistvo, samoubojstvo, samokrvlje. Štoviše, usporedi li se Benešićev rječnik sa suvremenim hrvatskim jednojezičnicima, vidjet će se da Benešić ima veći broj tvorenica, poglavito izvedenica. Primjerice, u tvorbenoj porodici koju čine tvorbena osnova bik- ili bogat- i njezini derivatemi Benešićev rječnik, uz lekseme koje bilježe Anić i Šonje, donosi brojnije mogućnosti derivacije:

10 Budući da leksikografska obrada u prvih dvanaest svezaka Benešićeva rječnika (a-rzati) nije bila sustavno provedena, neke natuknice nisu definirane, a ne nalazimo ni tipskog definiranja pojedinih leksičkih kategorija. 


\begin{tabular}{|c|c|c|}
\hline Benešić & Anić & Šonje \\
\hline $\begin{array}{l}\text { bik } \\
\text { bikar čuvar bika (bikova) } \\
\text { bikoboj borba s bikovima } \\
\text { bikonja augm. od bik } \\
\text { bikovati živjeti kao bik, } \\
\text { biti bik, vršiti funkciju } \\
\text { rasplodnog bika } \\
\text { bikovina pristojba od } \\
\text { neženjenih } \\
\text { bikovlji bikov, što je od } \\
\text { bika } \\
\text { bikovski što pripada } \\
\text { bikovima }\end{array}$ & $\begin{array}{l}\text { bik } \\
\text { bikača 1. žila goveda } \\
\text { izrađena kao sredstvo kojim } \\
\text { se udara; žila 2. razg. podr. } \\
\text { vrlo ili pretjerano snažna } \\
\text { ženska osoba; bikulja } \\
\text { bikić hip. od bik } \\
\text { bikijada neol. borbe } \\
\text { domaćih bikova; bodenje } \\
\text { bikonja razg. pejor. hip. } \\
\text { snažan čovjek, jak kao bik } \\
\text { bikovski 1. koji se odnosi na } \\
\text { bikove 2. koji je kao u bika, } \\
\text { bičji } \\
\text { bikovski pril. kao bik, na } \\
\text { način bikova } \\
\text { bikulja razg. pejor., v. bikača } \\
\text { (2) }\end{array}$ & $\begin{array}{l}\text { bik } \\
\text { bika 1. raz krupna krava } \\
\text { 2. pogr snažna, jaka } \\
\text { žena; bikulja } \\
\text { bikonja 1. uveć od bik } \\
\text { 2. vrlo jak čovjek, kao bik } \\
\text { bikovski 1. koji se odnosi } \\
\text { na bikove 2. koji je kao u } \\
\text { bika } \\
\text { bikulja 1. jaka krava koja } \\
\text { slabo daje mlijeka; jalova } \\
\text { krava 2. pren pogr vrlo } \\
\text { krupna žena; bika }\end{array}$ \\
\hline $\begin{array}{l}\text { bogat } \\
\text { bogaština bogatstvo } \\
\text { bogatac bogatun, bogataš } \\
\text { bogatar bogataš } \\
\text { bogataš } \\
\text { bogatašica } \\
\text { bogataški } \\
\text { bogataštvo bogatstvo } \\
\text { bogatinja bogatstvo } \\
\text { bogatir bogataš } \\
\text { bogatiti činiti bogatim } \\
\text { bogatiti se postajati } \\
\text { bogat } \\
\text { bogatlija bogataš } \\
\text { bogato prilog; obilno, } \\
\text { raskošno } \\
\text { bogatstvo } \\
\text { bogatun }\end{array}$ & $\begin{array}{l}\text { bogat } \\
\text { bogataš (bogatašica) onaj } \\
\text { koji je bogat; bogatun } \\
\text { bogataški koji se odnosi na } \\
\text { bogataše } \\
\text { bogataški pril. kao bogataš, } \\
\text { na način bogataša; } \\
\text { bogatunski } \\
\text { bogatiti (koga, što, se) činiti } \\
\text { bogatim, obogaćivati (se), } \\
\text { postajati bogat } \\
\text { bogato pril. dobro } \\
\text { opskrbljeno, s bogatstvom; } \\
\text { obilno } \\
\text { bogatstvo [...] } \\
\text { bogatun pejor., v. bogataš }\end{array}$ & $\begin{array}{l}\text { bogat } \\
\text { bogataš (bogatašica) } \\
\text { čovjek koji ima veliki } \\
\text { imutak; bogat čovjek } \\
\text { bogataški koji se odnosi } \\
\text { bogataše } \\
\text { bogataški pril. na način } \\
\text { bogataša, kao bogataš } \\
\text { bogatiti činiti bogatim, } \\
\text { bogaćivati - se povr } \\
\text { postajati bogat; } \\
\text { obogaćivati se - } \\
\text { bogaćenje gl im } \\
\text { bogato } 1 . \text { imućno } 2 . \text { na } \\
\text { bogat način; obilno } \\
\text { bogatstvo [...] } \\
\text { bogatun veliki bogataš }\end{array}$ \\
\hline
\end{tabular}


Premda motivirane sociokulturnim čimbenicima, dakle ondašnjim navikama i načinom života, navedene su tvorenice također i odraz tvorbene otvorenosti i bogatstva hrvatskoga jezičnog i književnog izričaja u 19. stoljeću. A kako Benešić nije imao normativnih pretenzija te je njegov Rječnik isključivo deskriptivne provenijencije, svi su stilistički sinonimi među sobom istovrijedni. Važno je tek da su potvrđeni u djelima od Antuna Mihanovića do Ivana Gorana Kovačića, dakle iz svih generacija kroz sto godina $i$ iz svih naših krajeva. Dakako, metajezik suvremenih hrvatskih jednojezičnika izgrađeniji je i kompleksniji, njihova je uloga normativna (Šonje) ili opisno-normativna (Anić) pa oni dajući uvid u hrvatski jezik u njegovoj pravilnosti uz pomoć stilskih odnosno normativnih odrednica određuju položaj istoznačnih leksema u jeziku. Primjerice, bogatun je u Anićevu rječniku određen pejorativno. Na kraju, valja naglasiti da su uz književnu produkciju 19. stoljeća važnu ulogu u leksičkoj obnovi hrvatskoga jezika onoga vremena imala i znamenita leksikografska djela, poglavito rječnici Ivana Mažuranića i Jakova Užarevića (1842), Bogoslava Šuleka (1854-1860) i Dragutina Antuna Parčića (1858), objavljena sredinom 19. stoljeća, koja donose velik broj novih tvorenica, pogotovo u području stručnoga leksika. Neke su od njih vjerojatno preuzete iz drugih rječnika, a neke je tezaurirao Benešić. Tako se uz danas sasvim uobičajene kao što su sladoled, velegrad i zubobolja u Mažuranić-Užarevićevu rječniku nalaze i ove novotvorenice: kipoklanjac, lažimudrac ${ }^{11}$, muhomor, nogolom, novinonoša, pravdoznanstvo, pričoslovje, rudokopje, samodrug, samosilnik, sitnozor, sviloprelac, tromonog, vodomjer, životopisac.

Međutim, kao posljedica izrazito konvergentne jezične politike koja se učvršćuje potkraj 19. stoljeća znatan broj virtuoznih tvorenica danas više nije svojinom hrvatskoga leksika, ne nalazi se u suvremenim hrvatskim rječnicima ni korpusima, a nije, dakako, ni dijelom razgovornoga jezika. Zaključak koji se ovdje nužno nameće jest da je razvoj hrvatskoga jezika od početka 20. stoljeća išao na štetu izražajnih mogućnosti i tvorbenoga bogatstva hrvatskoga jezika.

U svome djelu Standardni jezik Brozović 1970. godine upozorava da se spoznajama i saznanjima o hrvatskome jeziku u vrijeme jezičnih škola nije

11 U Benešića, primjerice, nema lažimudraca, ali se nalaze sljedeće tvorenice: lažiauktoritet, lažibogomolja, lažidjevojka, lažidoktor, lažienglez, lažifratar, lažikanonik, lažikultura, lažipjesnik, lažipoštenje, lažisvetac, lažišpanjolac, lažitalijan, lažitorba, lažiučenost, lažiučenjak, lažiustavni, lažizadranin. 
posvećivala nikakva pažnja, njihovi su nosioci bili „prikazivani kao posve beznačajni, izolirani i potpuno po strani od glavnoga razvojnog tijeka, to jest od linije Daničić, Jagić (ne mladi Jagić), Broz, Maretić - koja linija i nije bila glavna, nego je to tek postala [...] Dobri pisci toga razdoblja izdavani su pak u našem stoljeću s potpuno adaptiranim jezikom i naša publika zapravo i ne zna kako se pisalo od preporoda do 20. stoljeća. Tako smo se našli u aspsurdnoj situaciji da hrvatske pisce do preporoda izdajemo u originalu, a adaptiramo jezik u prozi romantizma i realizma!" (Brozović 1970: 141). ${ }^{12}$ Time se, dakako, stvarala iluzija da se jezik hrvatskih pisaca 19. stoljeća ni grafijski, ni pravopisno ni gramatički ni tvorbeno niti na razini leksika nije razlikovao od jezika suvremenih pisaca. Zato valja i opet istaknuti da $u$ Benešićevu rječniku od 13. sveska nadalje sve korpusne glose bilježimo dostojno povjerenja, dakle u skladu s izvornim zapisom, onako kako su pisali pisci hrvatski od preporoda do kraja Drugoga svjetskog rata. No, tek ćemo u 14. svesku, osvješćujući sve više dokumentacijski potencijal uvjetno nazvanih paralelnih korpusa, početi supostavljati korpusne glose koje pripadaju različitim izdanjima istoga djela, utemeljenima na različitim jezičnim koncepcijama i/ili ideologijama. Evo zasad samo jednog primjera:

Kad je stari Matković napokon uvidio [...] da su novci u njegovim rukama što i pljeva na vjetru, ne htjede mu više od 30 forinti mjesečno slati, te se uslied toga ljepušasti pravnik sve većma nazad povlačio i izjednačivao sa onimi sveučilištnimi gradjani, koji su više gladovali, nego siti bili (J. Kozarac, Mrtvi kapitali, 1890, 110).

Kad je stari Matković napokon uvidio [...] da su novci u njegovim rukama što i pljeva na vjetru, ne htjede mu više od 30 forinti mjesečno slati, te se uslijed toga ljepušasti pravnik sve većma povlačio s onim sveučilišnim građanima, koji su više gladovali nego siti bili (J. Kozarac, Mrtvi kapitali, 1924, 110).

12 O posljedicama prekrajanja i prilagodbama tekstova velikana hrvatske književnosti 19 . stoljeća postoji vrijedna literatura. Među ostalim: Hadrovics, L. (1983) Sprachliche Modernisierung kroatischer Klassiker in Neuausgaben, Festschrift für Nikola R. Pribić; Sović, I. (1985) Jezik Ksavera Šandora Gjalskog; Težak, S. (1993) „Nad Kumičićevim tekstom Urote zrinsko-frankopanske", Jezik, 41, 1, 1-12. Analizirajući jezik Ivane Brlić-Mažuranić Babić ponovo naglašava da je općenito poznato da hrvatske pisce 19. stoljeća ne možemo čitati u izvornom jeziku jer je njihov jezik poslije pobjede hrvatskih vukovaca "posuvremenjivan” (Babić 1995: 70). Daje i obilje primjera. 
Kad je stari Matković napokon uvidio [...] da su novci u njegovim rukama što i pljeva na vjetru, ne htjede mu više od 30 forinti mjesečno slati, te se uslijed toga ljepušasti pravnik sve većma nazad povlačio i izjednačivao se s onim sveučilišnim građanima, koji su više gladovali, nego siti bili (J. Kozarac, Mrtvi kapitali, 1950, 211).

\subsubsection{Hrvatski mladoekavci}

(ii) ali i primjere zajedničke prošlosti hrvatskoga jezika u zajednici sa srpskim. Između ostalog, građa Benešićeva rječnika svjedoči o tome da su brojni hrvatski pisci, takozvani mladoekavci, kasnih dvadesetih godina prošloga stoljeća upotrebljavali ekavicu i riječi poput angažovati, bitisati, buvara, ekser, hartija, (i artija), pod rastućim utjecajem ideja jezičnoga unitarizma.

Jedna manja sastavnica Benešićeva rječnika dokumentira i jezičnopolitičku praksu mladih hrvatskih književnika koji su potaknuti idejom hrvatsko-srpskoga jezičnog i pravopisnog ujedinjenja kasnih dvadesetih godina 20. stoljeća zagovarali pisanje književnih djela ekavicom. Naime, u to vrijeme jača pokret jugoslavenske orijentacije motiviran težnjama prema izlasku iz Austro-Ugarske i ujedinjenju sa Srbima i Slovencima. Mladoekavski pokret počinje slabiti nakon Vidovdanskog ustava iz 1921. godine, a definitivno poslije 1928. godine i uvođenja diktature, nakon čega je velika većina mladoekavaca ijekavizirala svoje tekstove (Samardžija 2012: 20).

Neki među mladoekavcima autori su korpusnih glosa u Benešićevu rječniku: N. Bartulović, A. Cesarec, D. Cesarić, J. Kosor, M. Krleža, G. Krklec, I. Krnic, A. Nametak, L. Perković, Đ. Sudeta, A. B. Šimić, T. Ujević. ${ }^{13}$ Tako je Ujevićeva zbirka pjesama Kolajna, objavljena na ćirilici 1926. godine u Beogradu, svjedočanstvom njegove rane ekavske faze:

13 Primjerice, u članku pod naslovom E A. B. Šimić obrazlaže svoju podršku izboru ekavice: „Dovoljno je jasno koji će dijalekat da nam bude zajednički ako kažemo da većina naših najboljih pisaca pišu ekavskim dijalektom, da rođeni „ijekavci” postaju ekavci (Dučić, Mitrinović, V. Miličević), da nijedan „ekavac” ne postaje „ijekavac” i po tom da je svaki dan sve više „ekavaca”, da sve manje „ijekavaca” u literaturi [...] Ne čekajući šta će reći filolozi mlađi su pisci nekada „ijekavci” počeli da pišu ekavskim dijalektom. Za njih je taj problem rešen, i oni idu dalje. Ostavljajući za sobom dokone kojima je volja da se natežu i da naklapaju. Mlađi dobri pisci ne trebaju filologa da ih uče koje će reči upotrebljavati [...] Moj jezik nije jezik kakva filologa. Jezik je život nerazumljiv filolozima" (Samardžija 2012: 44/45). 
Stupaj sa svojim mrakom / kroz propast horizonta, / sa tajnom $i$ oblakom, / od fronta pa do fronta. // Stupaj sa svojom tmušom / kroz ponoć cele zemlje; / pevaj sa svojom dušom / gde god se spava $i$ dremlje (Ujević, Kolajna, 1926, 3).

Mladoekavska je praksa jasno vidljiva i u korpusnim glosama iz Cesarčeva djela Careva kraljevina (1925) poput:

... tog Jurišića, to večno sumnjalo i fiškala bednih, najbolje je danas ne izazivati! (Cesarec, Careva kraljevina, 1925, 53).

Međutim, u ponovljenu izdanju Careve kraljevine iz 1946. godine ekavica je zamijenjena ijekavicom, a o dvjema jezično-političkim praksama svjedoče paralelne korpusne glose:

Toga Jurišića, to vječno sumnjalo i fiškala bijednih, najbolje je danas ne izazivati! (Cesarec, Careva kraljevina, 1946, 70/71).

Osim ekavice u korpusnim glosama zajedničku prošlost hrvatskoga i srpskoga jezika otkrivamo djelomice i u rječničkoj nomenklaturi, to jest na lijevoj strani Rječnika. Tu se, naime, nalaze riječi koje pripadaju srpskomu standardu, no koje su u svojim djelima rabili i hrvatski pisci. Primjerice, glagol ćutati u Kestenova krošnje - kraj prašnoga puta, / i ravnica plava, što svečano ćuta (Krleža, Simfonije, 1933, 34) ili imenica haos u Zaludu Buddha, Hristos, Mahler i Skrjabin / Nas haos melje, lud, strašan i vječit (Krleža, Knjiga lirike, 1932, 99).

2.2.3. Restauracija i reafirmacija posebnosti hrvatskoga jezika

(iii) oživljavanje izvorno hrvatskih jezičnih obilježja u vrijeme $\mathrm{NDH}$, poput morfonološkog pravopisa nakon pola stoljeća fonološkoga.

Uloga Benešićeva rječnika u dokumentiranju jezično-političke prakse u NDH u najmanju je ruku dvojaka. Naime, s jedne strane Benešićev rječnik otvara mogućnost potpunijega sagledavanja endehaizama odnosno ustaških riječi dokazujući da je najveći broj novih riječi u leksiku NDH nastao oživljavanjem leksema iz pasivnoga leksika, potvrđenih u djelima hrvatskih pisaca 19. i ranoga 20. stoljeća. ${ }^{14}$ Opširnije o tome u Nikolić-Hoyt 2013 a.

S druge strane, Benešićev rječnik neposredno svjedoči i o posljedicama direktivne jezične politike NDH koja je različitim zakonskim odredbama

14 Opširnije o tome u Nikolić-Hoyt 2013a. 
propisivala korienski pravopis i čist hrvatski jezik. Pri Ministarstvu bogoštovlja i nastave 1941. godine osnovan je Hrvatski državni ured za jezik kojemu je bila povjerena svekolika briga za čistoću i pravilnost govorenog i pisanog jezika. Uz izradu novog pravopisa ${ }^{15}$ i davanje službenih jezičnih

15 Iz Ministarske naredbe o hrvatskom pravopisu: [...] hrvatski se pravopis ima provesti na načelu etimološkom tako, da se utvrde sve etimološke mogućnosti osnovane na znanosti, koja ima odrediti svuda ono, što u duhu hrvatskog jezika nalazi svoju potvrdu. Prema tome dosadašnji školski pravopis mijenja se u ovim točkama:

1. Glas Đ ne sljubljuje se po zvučnosti, pa prema tome na pr. umanjenu riječ od ŽEĐA treba pisati ŽEĐCA mjesto ŽEĆCA; vodstvo mjesto vođstvo (voćstvo) i t. d.

2. Kod riječi muškoga roda, koje se svršavaju na -TAK i -DAK s nepostojanim A, suglasnici T i D ostaju ispred C bez promjene; dakle: početak - početci; patak - patci mjesto paci; zadatak - zadatci mj. zadaci; redak - redci mj. reci; dohodak - dohodci mj. dohoci; cvijetak - cvijetci mj. cvijeci, predak - predci i t. d.

Kod riječi sa završetcima -TAC i -DAC s nepostojanim A, GDJE JE POTREBNO OZNAČITI RAZLIKU U ZNAČENJU RIJEČI ČUVAJU SE OSNOVNI SUGLASNICI: na pr.: mlatac - mlatci; mladac - mladci i slično.

3. Kad nakon ispadanja nepostojanoga A od završetka -LAC muških imenica dodje glas L na kraj sloga, ne pretvara se u $\mathrm{O}$ i ne slijeva se prethodnim $\mathrm{O}$; na pr. stolac - stolci mj. stoci; dolac - dolci i t. d.

4. U imenima mjesta s nepostojanim A ne provodi se sljubljivanje, kad A ispadne; na pr. Medak - Metka mj. Medka; Gradac - Gradca mj. Graca i t. d.

5. Pravopisnom pravilu, da se glas $\mathrm{D}$ ne mijenja u $\mathrm{T}$, ako se nalazi u složenim riječima ispred $S, C, \check{S}, \check{C}$, Ć, kad se ovim glasovima počinje druga riječ u složenici prema čemu treba pisati: odsjek mj. otsjek, predsjednik mj. pretsjednik, odcijepiti mj. otcijepiti, odštetiti mj. otštetiti; kadšto mj. katšto; nadčovječan mj. natčovječan; odčušnuti mj. otčušnuti i t. d. - dodaje se:

U riječima, kojima se označuje viši ili niži položaj u odnosima službe, zvanja, zanimanja i sl.; Prijedlozi NAD i POD čuvaju glas D bez promjene; na pr. nadporučnik, podpredsjednik i t. d.

6. Nema sljubljivanja u tvorbi futura I. pa se piše rastavljeno: dat ću, past ću i t. d.

7. Ne ispadaju glasovi kod zamjenica pa se piše tko, netko, nitko, svatko.

8. Glas H se piše kod imenica na pr. duhan (ne duvan), kuhinja (ne kujna).

9. Strane se riječi pišu a) kako se pišu u jeziku iz kog potječu na pr.: Rousseau, Dumas, Goethe, Shakespeare b) kako ih je prisvojio hrvatski izgovor i pravopis na pr. Homer, Helen, historija, hereza, kemija, kirurg [...]

U Zagrebu, dne 23. lipnja 1941.

Doglavnik ministar bogoštovlja i nastave

Dr MILE BUDAK (Hrvatski narod, 26. VI. 1941, broj 132)

Međutim, Zakonskom odredbom o hrvatskom jeziku, njegovoj čistoći i o pravopisu od 14 . kolovoza 1941. godine, koju je potpisao Poglavnik, uvodi se ipak korienski pravopis koji, među ostalim, propisuje: 
savjeta ${ }^{16}$ Ured se bavio jezičnim i pravopisnim lektoriranjem rukopisa prije objavljivanja (Samardžija 2008: 39), odnosno jezičnim nadgledom svih tiskopisa uopće. Dakle, nije se mijenjao samo jezik pristiglih rukopisa, već se suprotno tekstološkim načelima preinačavao jezik dotadašnje hrvatske književnosti, $i$ to baš iz onog razdoblja, kad je ta književnost dala najveće mnoštvo izvornih $i$ prijevodnih djela (iz priloga zapisniku pete sjednice Jezičnog povjerenstva za hrvatski jezik, njegovu čistoću i pravopis od 12. studenoga 1941. u kojem se obrazlaže zašto bi trebalo zadržati dotadašnji fonetski pravopis (Samardžija 2008: 51).

1. Gdje je u ikavskom dugo i, postalo od ě (jat), ima se u hrvatskom književnom jeziku pisati ie, na pr. biel, cviet, diete, liek, riedak, svieća, tielo, zviezda, a gdje je u ikavskom govoru kratko i, postalo od ě (jat), ima se kao i dosad pisati je, na pr. djeca, mjesto, pjesma, susjed, tjerati [...]

2. Od jednosložnog dvoglasa ie valja razlikovati: dvosložni skup ie u tudjim riječima, na pr. hieroglif; dvosložni skup ije, koji je po postanju različit od ie. Takvo ije dolazi: u 2. padežu jednine i u 1. padežu množine imenica na -ija; biskupije, nacije, davorije, Ilije, pukovnije, zmije [...]

3. Izjednačivanje suglasnika po zvučnosti ne označuje se u pismu, na pr. gibka (od gibak), glasba, svatba, ženitba, grizti, izkaz, iztok, predpostavka, kadkad.

Imenice $s$ dočetkom -tvo (od starijeg -stvo), ako su izvedene od osnove, koja se svršava na c, č, k, g, z, ž, valja pisati s dočetkom -čtvo odnosno -žtvo, na pr. samačtvo, pjevačtvo, vojničtvo, družtvo, množtvo, knežtvo, lupežtvo. Isto tako i pridjevi s dočetkom -ki (starije -ski), kojima se osnova svršava na g, z, ž, pišu se dočetkom -zki odnosno -žki, na pr. englezki, francuzki, filoložki [...]

Slovo $\mathbf{n}$ izpred b i p ostaje, na pr. jeftinba, hinba, nastanba, obranbeni, zelenbać, jedanput, stranputica.

Slova d i t redovito ostaju iza s, z, š, ž u skupovima od tri suglasnika, na pr. bolestna (od bolestan), žalostna (od žalostan, bolestnik, častnik, dužnostnik, vjestnik, pestnica, mastnoća, vrstnoća, gostba, izvlastba [...]

Slova d i t redovito ostaju izpred c, č, s, š, na pr. srdce, dlietce, otca, sudca, dohotci, dobitci, Mletci, patče, sirotče, govedče, sudčev, mladčev, mlatčev, otčev [...]

8. Do izdanja novog pravopisnog priručnika vriede i dalje pravila, kako su propisana u VIII. izdanju Boranićeva pravopisa (od god. 1941.) i propisi ministarske naredbe o hrvatskom pravopisu od 23. lipnja 1941., koliko se ne protive ovoj provedbenoj naredbi (k zakonskoj odredbi o hrvatskom jeziku, o njegovoj čistoći i o pravopisu.

9. [...] poslie 1. siečnja 1943. zabranjuje se upotreba bilo kakvog drugog pravopisa [...] (Samardžija 2008: 149-153).

16 Primjerice: PRIRAD MJESTO PRIVREDA. ... se umjesto izraza: privreda, privrednik, privredni, privrednički, privrediti, ima govoriti i pisati: prirad, priradnik, priradni, priradnički, priraditi (Samardžija 2008: 480). 
Jezično-političku praksu NDH posvjedočuju, međutim, paralelne korpusne glose koje supostavljanju ranija, to jest prva izdanja iz 19. stoljeća i preinačena iz 1944:

... jedini predlog, od mnogih predlogah u kolu Iliracah, koga su njegovi drugovi ovako suglasno usvojili (Kovačić, Fiškal, 1882, 69). /... jedini priedlog, od mnogih priedloga u kolu Iliraca, koji su njegovi drugovi ovako suglasno usvojili (Kovačić, Fiškal, 1944, 73).

A žabari bi suglasno sa svojimi „dragimi ženicami” pred njihovimi švaljeri uzdisali nekim licemjernim pregaranjem (Kovačić, Medju žabari, 191X, 144). / A žabari bi suglasno sa svojim „dragim ženicama" pred njihovim švaljerima uzdisali nekim licemjernim pregaranjem (Kovačić, Među žabarima, 1944, 284).

Misli ostati do jeseni u svijetu i stvorio si o tom osobitu osnovu (Leskovar, Sjene ljubavi, 1898, 26). / - Misli ostati do jeseni u svietu i stvorio si o tom osobitu osnovu (Leskovar, Sjene ljubavi, 1944, 32).

\section{O paralelnim korpusima}

Dok paralelni korpusi predstavljaju važan alat za kontrastivna i terminološka istraživanja te su od neprocjenjive vrijednosti pri sastavljanju dvojezičnih i višejezičnih rječnika (Simeon 2002: 210), paralelne su korpusne glose, odnosno supostavljene citatne potvrde različitih izdanja istoga književnog djela sastavnim dijelom Benešićeva rječnika (od 14 . sveska nadalje) te, kao što smo već naglasili, pojačajno služe dokumentiranju jezično-političke zbilje stogodišnjega razdoblja u povijesti hrvatskoga jezika i književnosti. Štoviše, paralelne korpusne glose istodobno ukazuju na razvoj pravopisne i leksičke norme i na izvanjezični kontekst, to jest na vanjsku povijest jezika.

\subsection{Paralelne korpusne glose}

Kao što smo već rekli, zahvaljujući svojoj otvorenosti i nenormativnomu odnosu prema korpusu ekscerpiranih djela, odnosno prema uzusu pisaca, Benešićev se rječnik ukazuje kao vjerno svjedočanstvo, dokument vremena u kojem je nastao, kao i u njemu sadržanih povijesnih obrazaca mišljenja i djelovanja (Nikolić-Hoyt 2013b: IX). 
Međutim, dokumentacijski potencijal Benešićeva rječnika posebno dolazi do izražaja uvođenjem paralelnih korpusnih glosa od 14. sveska nadalje. Riječ je dakle o supostavljanju korpusnih glosa koje pripadaju dvama ili čak trima različitim izdanjima istoga djela koja pak odražavaju različite, često suprotstavljene pravopisne i druge norme. Dakako, ne pojavljuju se sva djela svih autora u paralelnim izdanjima, tek njih petnaestak, primjerice, Cesarec (Careva kraljevina 1925 i 1946), Gjalski (Pod starimi krovovi 1886 i Pod starim krovovima 1929), Kovačić (Medju žabari 191X i Među žabarima 1944, Fiškal 1882 i Fiškal 1944 te druge pripovijesti), Josip Kozarac (Mrtvi kapitali iz 1890, 1924 i 1950 godine i druga njegova djela), Leskovar (Propali dvori 1896 i 1944 pa i druge njegove pripovijesti), te Matoš (Iverje 1899 i Iverje. Novo iverje 1935 i drugo), Tomić (Kapitanova kći iz 1884 i Kapetanova kći iz 1935), Vojnović (Perom i olovkom iz 1884 i 1910).

Supostavljanje paralelnih korpusnih glosa sukladno je osnovnoj svrsi Benešićeva rječnika, dakle dokumentiranju jezičnih praksi određenoga vremena, različitih jezičnih navika i poraba, kao i stavova prema tim porabama, koje su velikim dijelom bile impregnirane prevladavajućim društvenopovijesnim, odnosno političkim i ideološkim kontekstom (Nikolić-Hoyt 2017: IX).

\subsection{Klasifikacija}

Paralelne korpusne glose koje se nalaze u 14. svesku Benešićeva Rječnika hrvatskoga književnoga jezika od preporoda do I. G. Kovačića pripadaju trima skupinama:

1. korpusne glose kao dio izvornoga hrvatskog izričaja iz druge polovice 19. stoljeća i njihove inačice u revidiranim izdanjima prve polovice 20. stoljeća, koja sukladno konvergentnoj a prevladavajućoj jezičnoj politici zanemaruju razlike između hrvatskoga i srpskoga jezika:

Osam dana blaženstva i zaboravi [...] časovi, u kojih je srce mladića ginulo al ujedno disalo zrak rafinirane svježoće ... (Vojnović, Perom i olovkom, 1884, 92). / Osam dana blaženstva i zaboravi [...] časovi, u kojima je srce ginulo al u vazduhu rafinovane svježoće ... (Vojnović, Perom i olovkom, 1910, 84).

Varoški notaruš je duša toga magistrata [...] on sudi parcem $i$ što on napiše, tu se ništa nemienja, to sudac samo treba da supodpiše 
i za drugo ga nije brige (Tomić, Kapitanova kći, 1884, 98). / Varoški notaruš je duša toga magistrata [...] on sudi parničarima $i$ što on napiše, tu se ništa ne mijenja, to sudac treba da supotpiše $i$ za drugo ga nije brige (Tomić, Kapitanova kći, 1935, 160).

Za kratko sam čuo, kako je neizrečeno sretan u svom braku [...] i da nikada - a mà ni k najbližim susjedom niti rodjakom ne zalazi, već neprestano čuči kod kuće sa ženom (Gjalski, Pod starimi krovovi, 1886, 103). I Za kratko sam čuo, kako je vanredno sretan u svom braku [...] i da nikada - a ma ni $k$ najbližim susjedima niti rođacima ne zalazi, već neprestano čuči kod kuće sa ženom (Gjalski, Pod starim krovovima, 1929, 89).

Nu o tom ne hćedoše oni, koji su mu dali štipendij, ni čuti, te tako Lešić poslije druge godine izgubi tu zemaljsku podporu (J. Kozarac, Mrtvi kapitali, 1890, 22). / Nu o tom ne htedoše oni, koji su mu dali stipendij, ni čuti, te tako Lešić poslije druge godine izgubi tu zemaljsku potporu (J. Kozarac, Mrtvi kapitali, 1924, 24).

2. glose koje pripadaju izvornomu hrvatskomu izričaju iz druge polovice 19. stoljeća i njihove inačice u izdanjima iz 1944. godine, koja su rezultat reafirmacije i restauracije autohtonoga hrvatskog jezika za vrijeme NDH:

Lice mu je gorilo, dočim je upravo ćutio, kako mu srcem probija neugodna studen, kano kada se voda na čovječjoj koži naglo pretvara u led (Kovačić, Fiškal, 1882, 31). / Lice mu je gorjelo, dok je upravo ćutio, kako mu srdcem probija neugodna studen, kano kada se voda na čovječjoj koži naglo pretvara u led (Kovačić, Fiškal, 1944, 36).

On još osjećaše na svom licu vlagu njezinih suza, a na njenim usnama, što se nakon tolikog stradanja nenadano nadjoše u slatkom cjelovu, počivao sanljivi, dražesni smiješak snatrenja (Leskovar, Propali dvori, 1896, 83). I On još osjećaše na svom licu vlagu njezinih suza, a na njenim usnama, što se nakon tolikog stradanja nenadano nađoše u sladkom cjelovu, počivao sanljivi, dražestni smiešak snatrenja (Leskovar, Propali dvori, 1944, 157).

Vrijedno je primijetiti da neke korpusne glose iz 1944. donose hrvatske jezične karakteristike koje se ne nalaze u prvim izdanjima. 
3. korpusne glose koje potvrđuju jezično-književnu praksu hrvatskih mladoekavaca dvadesetih godina 20. stojeća i njihove inačice u kasnijim ijekaviziranim izdanjima:

Tvoj večni sutra ipak je postao danas! I neka ostane večni danas, večni danas! (Cesarec, Careva kraljevina, 1925, 147). / Tvoj vječni sutra ipak je postao danas! I neka ostane vječni danas, vječni danas! (Cesarec, Careva kraljevina, 1946, 193).

Dva sasvim suprotna osećaja sukobe se na ruševinama Mutavčeve svesti (Cesarec, Careva kraljevina, 1925, 287). / Dva sasvim suprotna osjećaja sukobe se na ruševinama Mutavčeve svijesti (Cesarec, Careva kraljevina, 1946, 375).

Premda Benešićev rječnik kao vrijedna riznica jezičnopovijesnih podataka dokumentira jezično-političku zbilju od preporoda do I. G. Kovačića iz dubine svih svojih svezaka i svih interpretativnih razina, može se zaključiti da paralelne korpusne glose kao nov metodološki postupak od 14. sveska umnažaju njegov dokumentacijski potencijal, pridajući Benešićevu književnojezičnom rječniku snagu specifičnoga povijesnog dokumenta.

\section{Literatura}

Anić, Vladimir (2003) Veliki rječnik hrvatskoga jezika, Novi Liber, Zagreb.

Babić, Stjepan (1995) „Jezik Ivane Brlić-Mažuranić”, Jezik, 42, 3, 69-78.

Benešić, Julije (1985-1990) Rječnik hrvatskoga književnoga jezika od preporoda do I. G. Kovačića, I-XII, JAZU i Globus, Zagreb.

Benešić, Julije (2013) Rječnik hrvatskoga književnoga jezika od preporoda do I. G. Kovačića, XIII (s-spužvast), HAZU, Zagreb.

Benešić, Julije (2017) Rječnik hrvatskoga književnoga jezika od preporoda do I. G. Kovačića, XIV (spužvica-svunoćke), HAZU, Zagreb.

Brozović, Dalibor (1970) Standardni jezik, Matica hrvatska, Zagreb.

Brozović, Dalibor (2008) Povijest hrvatskoga književnog i standardnoga jezika, Školska knjiga, Zagreb.

Hrvatski narod od 26. VI. 1941., broj 132.

Matasović, Ranko (2008) Poredbenopovijesna gramatika hrvatskoga jezika, Matica hrvatska, Zagreb. 
Mažuranić, Antun (1859 [2008]) Slovnica Hèrvatska, Institut za hrvatski jezik i jezikoslovlje, Zagreb.

Mažuranić, Ivan - Jakov Užarević (1842) Deutsch-illirisches Wörterbuch Njemačko-ilirski slovar, Naklada i tisak privilegirane ilirske nacionalne knjigotiskare Dra. Ljudevita Gaja, Zagreb.

Nikolić- Hoyt, Anja (2010) „Uz dovršavanje Benešićeva rječnika”, Filologija, $55,61-87$.

Nikolić-Hoyt, Anja (2013a) „U pozadini rječnika”, Fluminensia, 25, 1, 151166.

Nikolić-Hoyt, Anja (2013b) „Predgovor”, Rječnik hrvatskoga književnoga jezika od preporoda do I. G. Kovačića, XIII (s-spužvast), HAZU, Zagreb.

Nikolić-Hoyt, Anja (2017) „Predgovor”, Rječnik hrvatskoga književnoga jezika od preporoda do I. G. Kovačića, XIV (spužvica-švrljuga), HAZU, Zagreb.

Samardžija, Marko (1995) Leksikologija s poviješću hrvatskoga jezika u XX. stoljeću, Školska knjiga, Zagreb.

Samardžija, Marko (2008) Hrvatski jezik, pravopis i jezična politika u NDH, Hrvatska sveučilišna naklada, Zagreb.

Samardžija, Marko (2012) Hrvatski jezik i pravopis od ujedinjenja do kraja Banovine Hrvatske (1918. - 1941.), Školska knjiga, Zagreb.

Šonje, Jure (2000) Rječnik hrvatskoga jezika, Leksikografski zavod i Školska knjiga, Zagreb.

Tafra, Branka (1995) Jezikoslovna razdvojba, Matica hrvatska, Zagreb.

Tafra, Branka, Petra Košutar (2009) „Rječotvorni modeli u hrvatskom jeziku", Suvremena lingvistika, 67, 87-107.

Tafra, Branka, Petra Košutar (2011) „Nova periodizacija povijesti hrvatskoga književnoga jezika”, Filologija, 57, 185-204. 
SUMMARY

Anja Nikolić-Hoyt

PARALLEL CORPUS GLOSSES AND THE DOCUMENTATIONAL POTENTIAL OF BENEŠIĆ'S DICTIONARY OF THE CROATIAN LITERARY LANGUAGE FROM THE REVIVAL TO I. G. KOVAČIĆ

Dictionaries based upon chronologically arranged excerpts of writings by 'the best authors' play an important role in the history of any national lexicography. An outstanding one, developed at the midpoint of the twentieth century and still under progress, is Rječnik hrvatskoga književnoga jezika od preporoda do Ivana Gorana Kovačića [Dictionary of the Croatian Literary Language from the Revival to I. G. Kovačić]. Conceived as an anthology of literary quotes, it documents the historical progression of the Croatian language, ranging from the mid-1800s, when the Croatian standard language was established and systematized, to the end of the Second World War and the beginnings of the Communist era.

Due to the fact that Benešić's dictionary merely registers language, employing a descriptive, documentary policy rather than a prescriptive and normative one, it includes various, at times co-existing linguistic practices, encompassing spelling and grammar and lexicon, as well as different, rather opposing political and ideological world views of the time in question. Accordingly, it records genuine Croatian literary tradition, dating back to the second half of the $19^{\text {th }}$ century, its lexicon as well as its prevailing spelling system and salient case and plural endings. In addition to this, it also registers linguistic habits belonging to the shared history of the Croatian and the Serbian language, marked by convergent and unitarian language policy, the beginnings of which date back to the late nineteenth century. However, it also documents the language policy of the fascist Independent State of Croatia (1941-1945), when genuine Croatian linguistic features were restored to life. In order to truly document the language of the cited period, we juxtapose (starting with volume 14), i.e. put within the same entry, corpus glosses/quotations that belong to two or even three different editions of the same work. As such, Benešić's dictionary is a valuable social and historical monument and a constituent part of the Croatian cultural and linguistic identity.

Keywords: Croatian language; Benešić's dictionary; parallel corpus glosses 